\title{
Gentrification in the mesh?
}

\section{Paolo Cardullo}

To cite this article: Paolo Cardullo (2017) Gentrification in the mesh?, City, 21:3-4, 405-419, DOI: 10.1080/13604813.2017.1325236

To link to this article: https://doi.org/10.1080/13604813.2017.1325236

\section{Published online: 08 Jun 2017.}

Submit your article to this journal ๘

Џ Article views: 252

Q View related articles $\asymp$

View Crossmark data \lceil

Citing articles: 3 View citing articles ๘ 


\title{
Gentrification in the mesh? An ethnography of Open Wireless Network (OWN) in Deptford
}

\section{Paolo Cardullo $\odot$}

\begin{abstract}
The paper offers a critical perspective on practices of construction and consumption of wireless mesh networks in urban environments. It narrates Open Wireless Network (OWN) in Deptford, at a time when this inner borough of London was undergoing an intense gentrification process. Drawing on critical urban theory, the ethnography frames $O W N$ as a sociotechnical assemblage deeply entangled with everyday city life. It argues that gentrification poses challenges to a grass-roots wireless network like OWN, because it risks reducing it to an individualised utility and an aesthetic provision. The initial findings suggest the communitarian construction of this wireless network has helped to maintain a commitment to reciprocity, potentially offering - for its users, developers and participants-pockets of resistance against their cultural displacement. Although providing free wireless broadband to many, the paper argues that wireless communication became of secondary importance to the locals who joined the network. For years in fact, OWN contributed to face-to-face interventions, local knowledge exchange and transfer of competences, becoming a relatively known presence in the area. The research operates on a multidisciplinary level evoking hackers, technology and the production of urban space. It wants to stitch back together some of the literature on socio-technical assemblage and on the 'right to the city'.
\end{abstract}

Key words: wireless networks, gentrification, civic hacking, ethnography, displacement

Introduction

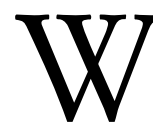

hile writing my $\mathrm{PhD}$ research on the gentrification of East Greenwich riverside (London, 2012), I became involved in making my own web project. ${ }^{1}$ A friend introduced me to a local weekly drop-in workshop on Linux-based solutions called 'Wireless Wednesday'. There I met a group of hackers and computer enthusiasts who introduced me to the Free and Open Source Software world, and the hands-on, learning-by-doing, approach to computer technology. I became part of Open Wireless Network (OWN)-a free, community-built, Wi-Fi network between Greenwich and Deptford-and for many years I hosted a node in my own flat. ${ }^{2}$

As a consequence, the paper maintains a multidisciplinary approach to wireless communication. Firstly, it draws on critical scholarship, putting gentrification-and the displacement of working-class residents that it produces-as central to city change (Brenner 2009; Harvey 1978; Slater 2006). It 
then uses a critical reading of the Social Construction of Technology (SCOT) (Bijker 2010; Klein and Kleinman 2002), suggesting that the production of urban space is crucial to the development of such technologieswireless networks are, after all, very local and territorial. The paper suggests that the 'rights claims' hackers and users of OWN make, by way of producing, circulating and using such a network, are part of a broader claim: a 'cry and demand' for a more equal city (see Isin and Ruppert 2015; Marcuse 2009).

Of course, the claim for a 'just city' appeals to both the development of the Internet and the surrounding urban space. As Graham (2004, 16) effectively puts it, 'information society is an increasingly urban society'. Cyberspace is thus a social space ruled by the same trajectories and power relations we can observe elsewhere (Isin and Ruppert 2015). Both cyberspace and city space can be described by the way in which bodies move through them. They are traversed by daily local journeys (Knowles 2010) and electronic mobilities (Graham 2005). Bodies generate broader rights demands because they belong to people that are, at the same time, city dwellers and receivers-producers of wireless communication. This study thus understands 'the problem' of wireless networking-privacy, communication, freedom-in conjunction with 'the problem' of city space-how it is produced, governed and lived.

The paper suggests that gentrification poses challenges to grass-roots wireless networks like OWN because it risks reducing it to an individualised utility. This is a consequence of the process of neo-liberal reorganisation of urban space that displaces workingclass residents and their dispositions towards others (Skeggs and Loveday 2012). I would argue that this disposition was essential to the development of OWN. Although providing free broadband to many people in the area, wireless communication became of secondary importance to the participants of OWN. During almost a decade of activity in the area, OWN rather contributed to face-to-face interventions, local knowledge exchange and transfer of competences, as well as to some instances of anti-gentrification activism.

First, I introduce the neighbourhood within which the nodes that make up OWN are located. I take a socio-historical perspective on its recent changes (see Back 2015, 833), in order to help readers to contextualise the spatial implications of OWN with regards to this peculiar part of London. I then discuss some of the literature on urban infrastructures and on wireless networks, with particular attention to the social 'context' in which technologies are made. This context includes the surrounding city, and this is something that is not always given. While some early contributions to wireless networks research seem to suggest a deterministic development of digital citizenship (Bar and Galperin 2004; Foth 2006), others integrate urban space and digital infrastructures without explaining how the former is produced (see Antoniadis and Apostol 2014; Foth 2003; Foth et al. 2009).

Extracts from my fieldwork material occupy the central part of the paper. They comprise of five years of participation to 'Wireless Wednesday' workshops, a space where discussions about, and practice of, technology happen weekly. They also include many clues derived from elicitation through photographs, 'obsolete' technologies, stickers, logos, and hand-drawn charts and maps. Workshop goers have been generally unwilling to sit and let me record conversations that I have had with them, resulting in the research being based on relatively few 'official' semi-structured interviews, about 10. However, I have had a myriad of interactions with those involved with the project and I have noted the gist of these in my research diary. These have included several important comments and jokes, something that hackers are always keen to perform (Coleman 2012). For the reasons that I mention above, most of the interventions by those involved in OWN are anonymous.

As a narrative device, as well as data point in its own right, I present panoramic 
photographs from the OWN archive. These were employed for photo-elicitation purposes, meaning that they were used for a discussion with the participants around the subjects and spatial relations in the photographs as they appear to them (Harper 2002). Photo-elicitation gave me a chance to capture details from the social history of this peculiar network, made up of technologies as well as people and their daily urban experiences. For example, I had talks with James, the founder of OWN, relating to which of the photographs to include in this paper. These photographs stimulated my sociological imagination: they dictate the tempo and draw the storyline along which the ethnographic narrative unfolds.

I kept the paper open and participative throughout, although it has not been written together with the participants, and it is not a wiki page where any subscriber is allowed to amend it. Like the social construction of the wireless network, however, the paper underwent attempts, corrections and it was altered according to a number of suggestions. I have often edited the draft while sitting at bitspace, and sometimes the people there interacted with the text and photographs as these progressed. ${ }^{3}$

The account that I narrate partly wants to convey this experience of intimacy with 'hackers' and computer technology. More importantly, it speaks from the social landscape and the urban experience within which both technology-makers and myself were residing: inner-city Deptford. It wishes to connect the ways in which the city is produced and lived with the ways in which the wireless network develops. This is the theoretical and methodological framework through which I understand some of the lives and technologies that I narrate here.

\section{Icarus ascending}

'One very pleasurable aspect of open wireless networking is the regular opportunity to view these panoramas from high up on rooftops and high-rises as we travel about installing equipment.' (James, founder of OWN)

Figure 1 is taken from the top of the tallest council block in London, Daubeny Tower, which is one of three 24-storey buildings completed in 1962 and part of the large council-owned Pepys Estate in Deptford, South East London.

$\mathrm{OWN}^{4}$ aerial installers look down towards residential Deptford. This is an inner borough of South East London with a working-class history, as well as one of sustained migration, both linked to the nearby Thames (Back and Lyon 2012; Steele 1993). The installers' gaze is immediately put to work into framing some sort of network map: they discuss possible obstacles to the transmission of wireless signals, such as buildings or trees; meanwhile, they are also scanning the landscape for potential points of contact, somewhere down below, pointing to other known hosts of the network.

In 1991, a more famous panorama was drawn over Deptford riverside, a geography that has profoundly altered this social landscape and will no doubt continue to do so for years to come. When Tory minister Michael Heseltine launched the 'City Challenge' regeneration plan, the London borough of Lewisham participated, with its small riverside in Deptford, mostly occupied by the vast Pepys Estate and Creekside (see Centre for Urban and Community Research 1997). ${ }^{5}$
'Heseltine was taken up into the sky over Deptford's mass of derelict social housing and he toured the run-down industrial estates in helicopter. The landscape below him was almost literally turned into a map that was subsequently recognised as a space of governmental intervention.' (Keith 2005, 76-78)

As part of the plan, Lewisham Council sold Aragon Tower, the one closest to the river, to Berkeley Homes, which completed the newly re-branded ' $\mathrm{Z}$ Apartments' in 2006. These featured no social rented 


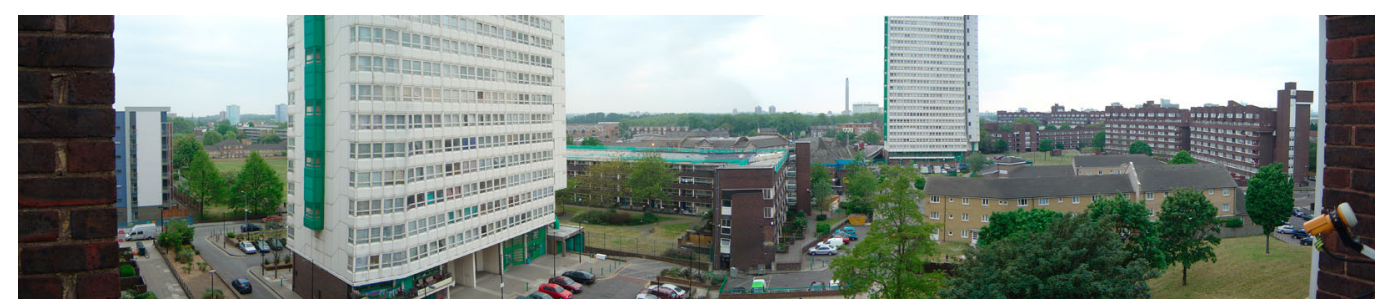

Figure 1 Pepsy Estate Deptford. Middle ground view (Source: sps.org archive, Creative Commons license).

accommodation and four additional floors with 14 luxury penthouse apartments. The story was captured over the course of three years in a BBC documentary entitled The Tower: A Tale of Two Cities, which won the BAFTA award in 2008. The Dickensian opening of this eight part series sets the pace of the documentary: 'London, for the people who live here, it can be the best of times and the worst of times' (BBC 2007). Wealthy newcomers are shown being taken to Deptford by boat. They are often filmed drinking wine and looking over the Thames, towards Canary Wharf and Greenwich Reach. The gaze of these new residents is turned away from inner-city Deptford, which remains a cause of concern for their own safety. The loud presence of the locals is often felt, but only from the safe distance of the tower heights (see Back 2009). Pepys Estate residents responded to the BBC documentary in a participatory video, funded by the Joseph Rowntree Foundation (Spectacle and JRF 2008). They exposed the BBC narrative as one that systematically profiled people and events as the poor 'other'.

These vignettes will give readers a sociohistorical insight about the urban space in question, while conveying the two main themes developed in this paper. One suggests that riverside Deptford is experiencing a wave of gentrification whose effects are felt deeply by local working-class residents. The second is that wireless networks do not happen in a vacuum. 'Hackers' and users of OWN are also urban dwellers and residents of this quickly gentrifying neighbourhood. Technology and gentrification are part of their daily experience of place, and these are here connected in the sense that the paper tries to untangle.

From the top of Pepys tower blocks we now descend into the streets of inner Deptford, following wireless signals from a home-made mesh network which is inspiringly called OWN.

\section{A bunch of aerials}

\begin{abstract}
'You have a bunch of aerials and they exchange info. Each point on the network, nodes, can act as a repeater and access point. OWN also provides Internet connectivity and this is shared over the mesh. Because of the speed involved, it is not good for videos, but it is for general browsing.' (OWN host)
\end{abstract}

I sit in a bright living room in one of the first flats to have had a node. The host speaks at length of his involvement with developers and technologies of the network. We both relax at the understanding that our conversation was not around the codes and protocols behind OWN: 'I am not sure about the technical details', says my interviewee, although he provided the accurate description given at the start of this section. At the end of our chat, he invites me to see the aerial on the rooftop. This expands wireless signal (and ultimately free broadband) to the High Street below. It is a sunny market day in Deptford: the street looks like many busy inner-city landscapes, packed with people, goods, and all sort of sounds and odours. Back and Lyon (2012) put it beautifully when they describe the market as 'the stuff of and for the everyday, and it has an ordinary, unpretentious feel, serving a mostly 
local clientele of Afro-Caribbeans, Chinese and white British'. Despite the fact that the network is designed around anonymity, my host immediately translated the provision of OWN into a form of gift economy in this street below: 'I told someone in the market once: you can get a bit of a free Internet if you need it.'

Open Wireless Network started in 2008 from the rooftops of SPC, an iconic hack space on the border between Greenwich and Deptford, although, as James proudly explains, 'we already made a mesh network to Deptford in 2001: a bit like playing with radios and walkie-talkies'. He is the founder of OWN and the facilitator of a myriad projects, workshops, hacks and installations. Soon after its establishment, OWN had over 60 nodes and about 400 users at any one time, mostly along the Creekside. In the last few years however, the project went through a period of disinterest and decline because 'with so many people carrying Smart phones, Tablets and Laptops, many with 3 and $4 \mathrm{G}$ network access as standard, some of the passion for independent infrastructure building has fallen away'. ${ }^{6}$

Wireless technologies promised a structural change in the way we communicate in cities, made of ubiquitous connectedness and freedom from centralised control. Due to lack of cabling, wireless connections potentially boast high performance for relatively limited costs (Akyildiz and Wang 2005). Mesh networks became popular during the early 2000s, when Wi-Fi protocols were standardised. Bar and Galperin (2004) suggested that it is possible to imagine a future in which ad-hoc networks spontaneously emerge when enough Wi-Fi devices are present within an area' (274; emphasis added). Rapidly diminishing costs in Wi-Fi equipment, flexible policies and the emergence of a myriad of contractorssuch as cooperatives, small Internet Service Providers (ISPs), business and local authorities-have been critical factors in wireless network resilience and popularity, at least in the Global North (Forlano et al. 2011).
There is now a significant literature around the relationship between urban space and communication infrastructures. Graham and Marvin (2001) pioneered critical research trajectories in this field by linking technologies and infrastructures with the 'urban condition'. They suggested that, under the urban process of capitalist accumulation (see Harvey 1978), physical and socio-technical infrastructures generate the fragmentation of services and utilities, with their privatisation, commercialisation and reduction to individualised consumer choices. 'Splintering urbanism' was a turning point in the way in which infrastructures became woven into narratives of city change and development. I maintain that Graham's concerns for the splintering of infrastructures, around social and cultural dimensions of space and class, are still valid in relation to wireless networking for three main reasons.

Firstly, because funding is a critical issue for the development of independent wireless networks (see Forlano et al. 2011). The ability to allocate resources, bandwidth and speed, remains important. A more robust bandwidth, for example, allows a higher number of users to be connected at any time.

Secondly, because wireless networks are often increasing the gap between developers and the users of the mesh (Medosch 2015). In fact, many networks have evolved towards a commercial model, acting like ISPs: wireless is often experienced passively as access to the commercial Internet with no engagement with the technology that makes it work. Medosch's critique underscores the very notion of participation to the construction of wireless technology.

Thirdly, because gentrifying neighbourhoods imply the geographical displacement of people committed to the cause of the 'commons', such as hacktivists, but also, in my own focus, working-class residents. As has been documented at length (Marcuse 1985; Slater 2009), gentrification brings forms of cultural displacement as gentrifiers boast new attitudes, models of consumption and lifestyle expectations. These sit at odds 
with the politics and practices that networks like OWN have delivered. I will return to this important point towards the end of the paper.

To further understand the social dynamics around technology, I now draw on a critical reading of the theory of the SCOT (Bijker, Hughes, and Pinch 1987; Klein and Kleinman 2002; MacKenzie and Wajcman 1985; Prell 2009). SCOT suggests an anthropologicalhistorical approach to the study of technological development, asking bow technology is made and how it is used: a process of unboxing technologies that is alternative to technological determinism. The singularity of each technological assemblage and the social milieu in which knowledge is acquired are thus given relevance (Kitchin and Dodge 2011). Design of technologies becomes a narrative within a relevant group (e.g. hackers), where alternative uses of technological objects are sought, and peculiar power relations are developed (see Alleyne 2011). Unsurprisingly, scholars adopting this framework prefer a qualitative approach such as participant observation, interviews, ethnography, archival record collection and other forms of historical analysis.

For Forlano (2008), the social construction of wireless technology makes evident the disjuncture between media representation of ubiquitous connectivity and its everyday use. In trying to go beyond the rhetoric of 'anywhere, anytime', this paper wants to communicate the great amount of time, effort and dedication that some have put into the installation and maintenance of OWN:

'5-6 years ago, James brought "the box", dug a hole in my bedroom, run the cables to the roof. He made a bit of a mess [laugh] but it was all right. We had rain water coming in once and "the box" had to be changed.' (OWN host)

The provision of nodes was regulated by a small one-off fee to contribute to the costs of 'the box' (mesh router and, sometimes, aerial). OWN developers dedicated a lot of voluntary work in maintaining the network:
'From a sociological perspective what is remarkable is the sheer array of stuff, people and places involved in making and re-making Wi-Fi', suggests Jungnickel $(2014,3)$. Wirelessness is now questioned in terms of its 'banal' socio-technical implications (Mackenzie 2011; Michael 2006), in/ visibility (Graham 2010; Jungnickel 2014) and control that it might generate (Kitchin and Dodge 2011).

In making 'things' work, there is an intense process of negotiation and knowledge transfer between users and developers of the network. For years, users and hosts have been meeting every week in drop-in training sessions, called 'Wireless Wednesday', at bitspace. This is a social technical club for chitchats revolving around communication technology: computers, primarily, but also mobile phones and anything in between: 'It's an open space for people who use OWN to come down and discuss issues they have with it, or whatever really.' In a relaxed atmosphere, around biscuits and tea, software and hardware seem to come alive in unexpected performance (see Mackenzie 2005): 'I think the proper social network is bitspace. Only when things break down or don't work, people want assistance', suggests another host of the network.

The technologies that we take for granted in our everyday practices do in fact demand induction, participation and care. This is where training and support become strategic, enabling a bond dictated by practice. The knowledge transfer generated during the informal training, and the social capital produced, are crucial to the project: 'OWN was to expose the idea of mesh network in a way that people would get an experience that was both practical and informative' (James, founder of OWN; my emphasis).

\section{The place of space in wireless technology}

Recent literature on urban wireless networks rightly suggests taking into account at once technology, people and urban space (see 
Forlano 2009; Foth, Choi, and Satchell 2011). A multidisciplinary approach to mesh networks like OWN, in fact, can be crucial to a better understanding of city inequalities, in terms of power or access to infrastructures of communication. It allows to unpack place from a technology-centred perspective. Simultaneously, it starts from the production of urban space to get to a better understanding of technology-making.

However, the literature seems to have neglected a critical perspective on how space works: 'Media studies appeared less prone to "following through" to the level of spatial production' (Tarantino and Tosoni 2013). For instance, despite drawing on Lefebvre's scholarship, Foth et al. (2009, xxviii) uses the metaphor of 'city-body' in order to integrate urbanism and media ecology: 'How do the cells of the city cluster to form tissue and organs?', that is, 'How do various systems communicate and interact with each other?'

Moreover, 'hybridity' appears to regain popularity. This tries to capture the complication of living an online experience embedded in physical places and limited by material resources (cables, radios, access). According to Antoniadis and Apostol (2014), hybridity is a crucial concept, whereas the 'virtual space is a layer of the physical urban space': digital and physical worlds are here kept apart, although they are also intertwined. $\mathrm{Hu}$ (2015) deconstructs the disembodied imaginary and symbolisms conjured up by the cloud (or the 'network of networks') by looking at the historical infrastructures that underpin networks and cloud computing. He writes, 'The cloud, as an idea, has exceeded its technological platform and becomes a potent metaphor for the way contemporary society organises and understands itself' (Hu 2015, xiii). For Forlano (2013) 'hybrid notions do not go far enough in advancing theories around urban technology and the role of place'. Urban technology, she further suggests, is a 'rather quite incongruous process' which does not happen in layers. Her 'new lexicon' for media and the city, however, is yet to include gentrification and displacement.

Wi-Fi networks like OWN mostly operate by strengthening social interactions and relations on the ground, rather than in an imaginary cloud-space. The cultural disposition of people directly involved in using the wireless network is, in my view, the crucial element that sustained the mesh. The following extract shows an underlying commitment in caring for other people around, and in sharing the limited resources one has:
'A similar project [to OWN] was done by James and a few others in an estate in Kingston, South West London, in 2007-2008. It was a huge estate. And they found that very few people were taking up the free Internet and you know why? No one could really afford a computer. Hardware was still quite expensive ...' (OWN host)

This is a space characterised by digital divide which turns out to also be a space of struggle and displacement caused by unequal access to housing, services and lifestyles. There are moments in which the 'pressure of displacement' on my interviewees, both hackers and users, is already acute. Marcuse (1985) describes this as a psycho-social condition, which includes the changing composition of neighbourhoods and lifestyles: shops become expensive, the neighbourhood is considered to be less friendly and familiar because attitudes change, spaces are sanitised and previous social networks end up being largely dispersed. At bitspace, talks about affordable rent solutions sometimes intertwine with discussions about switches and cables. Meanwhile, the new artisan bakeries on Deptford High Street are sometimes described as selling 'posh bread'.

Since infrastructures are simultaneously ecological and relational, they are particularly productive in showing emotional investments, social suffering and exclusion (Larkin 2013; Rodgers and O’Neill 2012; Star 1999). The study of infrastructures thus reveals social orderings nested in everyday practices. This is because infrastructures 
both deliver and are the 'stuff' of every day, such as water, electricity, waste disposal and, of course, the Internet (see Larkin 2013).

We can formulate each of the research questions contained in this paper-city space as the 'context' in which the wireless network develops and, consequently, how the gentrification of this space might influence such an infrastructure-by looking at the panoramic photograph and map (Figures 1 and 2). In the former, the relay node 'listens' to a router which has access to the public Internet, at the bottom of the opposite tower: 'The shop at the corner [of the Pepys tower block] is actually a community space, Coopepys. ${ }^{7}$ We used to have four routers on the Pepys Estate for many years', says James while looking at the photograph. In such an enclosed built environment the wireless wave seems to be, and eventually is, deeply constrained. At the same time, each resident of the surrounding flats, as well as their visitors and passers-by, becomes a potential host or user of an ever-evolving network. Each installation, connection and support narrates a different story of trust, friendship, negotiation or betrayal; of new relations and commitments; of frustrated attempts and successful experiments; and of outreach towards potential node hosts or new vantage points to exploit.

Similarly, the Google-like map of OWN shows proximities and links between different nodes. In an online 'live' version of this map, hovering the mouse or clicking on the node icon, one was able to see the number of users connected to each of them. The flatness of this cartography simplifies the workings of the network, making it legible as a metaphor of data flow. It immediately makes visible the taken-for-granted waves of Wi-Fi connectivity. The map, however, erases the entanglements of people, buildings and infrastructures, as well as the limitations and opportunities offered by technology and urban environment.

These two images hopefully convey ways in which 'the urban' contributes to stretch wireless technologies. OWN was not a corporate project of infrastructure provision and control, but a patchwork improvisation that takes pieces from lots of provision networks: the evolving wireless network maintained a status of an utterance in the planned and organised city, made and remade in response to new problems and solutions, encounters and exchanges, which cities are ready to offer. A daring question around OWN would then be about the impact that the gentrification of Deptford has on its functioning, especially in proximity of its Thames and Creek riversides (see Davidson and Lees 2005)?

I will complete the 'Fall of Icarus' (de Certeau 1984) to the streets by narrating the story of some participants to OWN. The social activity which goes alongside maintenance of the network generates a different connectivity made of very material and face-toface encounters on the ground, which probably have little to do with the promises of ubiquitous wireless connection (see Cardullo 2017). The circulation of affect and actions this connectivity generates is rather an established working-class disposition for sharing and living with, supporting and helping others (see Skeggs and Loveday 2012). My ethnography thus suggests that the social landscape of Deptford has been partly responsible for the development of OWN.

\section{Icarus descending}

At the bottom of the Pepys tower block, in the reach of Coopepys node, a mural shows the outcome of a resident-led renovation project. Pete Pope, a well-known Deptford resident, contributed to its making. Although Pete never owned a node, he was actively following the development of OWN. In Figure 3, he is seen setting up an aerial in Deptford adventure playground. Pete was a 'regular' at the weekly workshops, 'Wireless Wednesday'. This space has been a catalyst for knowledge transfer: some users in fact became producers of OWN, in the sense that they contributed to share software 


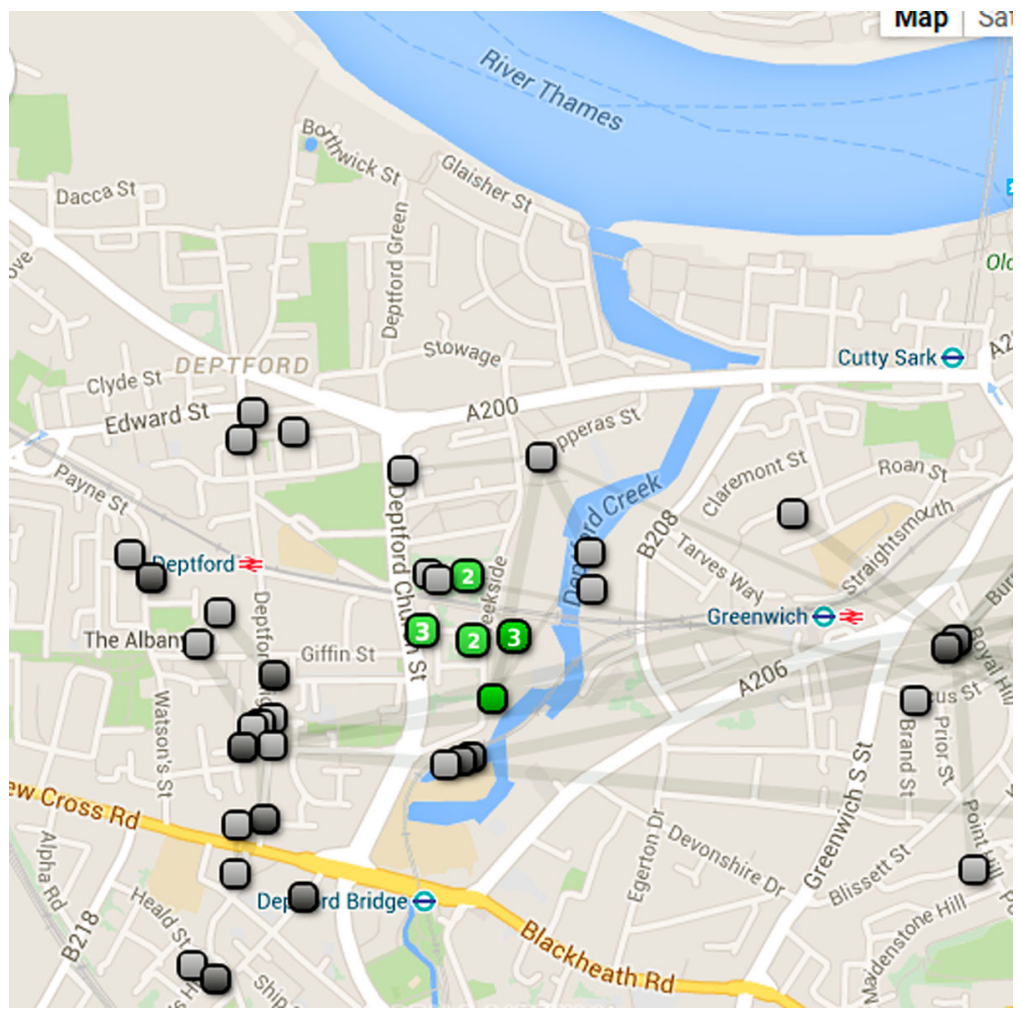

Figure 2 OWN, Live network map 2015 (Source: Author. Creative Commons license).

solutions, provide some hardware maintenance ('the box', cables, aerials, laptops) and bring free wireless provision to others (through word-of-mouth or outreach).

When Pete prematurely passed away, hosts and known users of OWN as well as friends and community activists started a cheerful and noisy procession from the local Birds Nest pub, another space that had been hosting a node for a long time. Pete 'walked' once more along the Creekside in Deptford, passing by some of the nodes along the Crossfield Estate. This was constructed in 1930 as part of a first regeneration effort in the area, close to the docks and slaughterhouses on the Creek. A turning point in the history of the estate was the mid-1970s decision to favour occupancy there for young single professionals - teachers and students from the nearby Goldsmiths for instance. ${ }^{8}$ This started a cultural shift in the area, a first wave of gentrification, that sat side by side with the local workingclass population (Glass 1964, in Slater 2009).

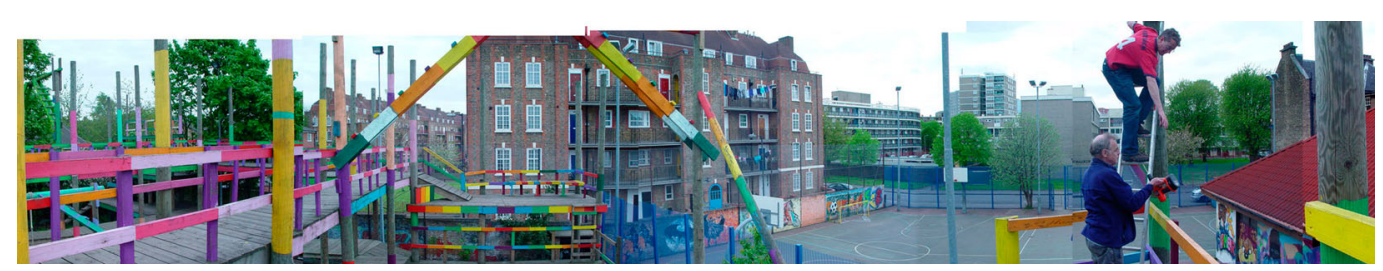

Figure 3 Setting up OWN aerials in Adventure Playground. Deptford (Source: sps.org archive, Creative Commons license). 
The Crossfield Estate has been rightly included in the 2012 conservation plans for the Creekside, because of its 'high social value for residents, artists and the Deptford gay community' (Lewisham Council 2012). This now feeds into a narrative of Deptford as a 'long-term cultural hub' and positions creative middle classes as a civilising force in the Deptford cultural landscape.

Pete's last walk symbolically ended on the Ha' Penny Hatch Bridge. This is a little bridge on Deptford Creek which connects the densely populated estate to Greenwich and its historical amenities. It was eventually built in 2002 as part of the Creekside regeneration programme (Small Regeneration Budget), thanks to the struggle of local activists and residents, including Pete. His ashes were scattered there, in the water near the Creekside Discovery Centre, where yet another OWN active node was located.

Creekside is the latest gentrification frontier in Deptford. It has all the ingredients for a cocktail of urban change and displacement. As most of Deptford, it has a large concentration of migrant population, and this historically carries a potential for higher differential in rent (Keith 2005). Deptford Creekside is a short distance from Canary Wharf and Greenwich, and this stimulates the demand for new housing among highflying brokers and heritage lovers. Newbuild housing on the Creekside now commands over $£ 700$ per square foot, 'reflecting the significant latent demand for high quality residential accommodation, strong investment and lifestyle attractions of the area'. ${ }^{10}$ Among these attractions is Deptford's 'vibrant' cultural quarter: according to the marketing material for the new-build Creekside Village, ${ }^{11}$ Deptford is 'the new Shoreditch' with 'more artists per square mile than anywhere else in the capital' (see also Harris 2012; Pratt 2009). The dynamics between cultural quarters and the displacing forces of capital are thoroughly analysed by Keith (2005) (see also Lawton, Murphy, and Redmond 2014). These forces incorporate the rising importance of cultural industry and the promotion of multiculturalism into preferences for new housing. Gentrification is now an endeavour much larger than the differential in rent. Rather, as Neil Smith has put it, it is 'the class remake of the central urban landscape' (cited in Keith 2005, 121) (Figure 4).

There is an intrinsic paradox in framing Deptford as a 'cultural quarter' since many warehouses on the Creekside, which once hosted affordable art studios, have now been demolished in order to make room for new upmarket developments. This is a dilemma that private developer-driven regeneration of cities brings about. As places become 'cool', they inevitably attract new capital, which ultimately erases the character that initially made places attractive to investors and private buyers.

Pete had a certain attachment to these waters. He notoriously dressed up as Lord Nelson to protest Convoys Opportunity's Plan. This aimed to turn the dismissed Convoys Wharf on Deptford Reach into a cruise liner terminal with annexed luxury developments. ${ }^{12}$ His face now appears on the 'Wall of Ancestors', a sculpture that commemorates famous residents of Deptford, at the bottom of the ' $\mathrm{Z}$ Apartments', as these are now called. In an interview realised for Deptford.tv, another project connected to OWN developers, Pete declares: 'This socalled "regeneration process" has been grinding across Deptford for the last 20 years. ${ }^{, 13}$

The story hopefully gives the sense that OWN has been more than a free wireless gateway to the 'commercial Internet'. I would argue that OWN was an experience intertwined with users' daily geography of gentrification and displacement (see Lees 2000). I have shown this by describing the efforts to maintain a functional network across council flats and estates, as well as to outreach new users and nodes around this peculiar neighbourhood.

OWN expressed a gift economy made of shared broadband as well as ongoing maintenance of software and hardware. As one host suggests, 'I think OWN is a shared 


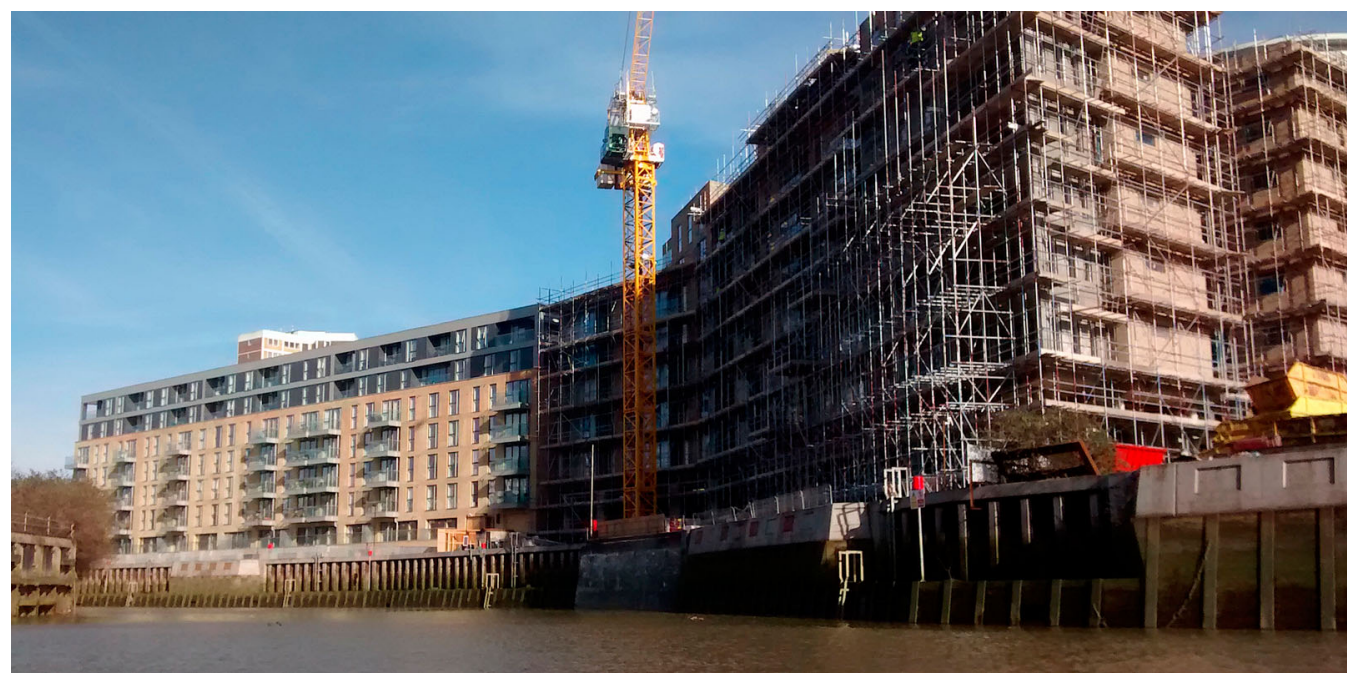

Figure 4 Deptford Creekside. View from the water (Source: Author's photo. Creative Commons license).

resource and that's what makes it a little bit more interesting.' To my mind, Pete's sendoff further shows this disposition towards the commons, as circulation of affect. In their study of working-class personhood, Skeggs and Loveday (2012) invite us to think of 'value' not just in economic terms (accrual of various forms of capital), but also 'relationally, as a more general ethos for living, for sociality, and connecting to others, through dispositions, practices and orientation' (475-476). I would argue that
OWN contributed to building and circulating a certain type of experience rooted into the social fabric of working-class Deptford: 'OWN is about local people who give a bit back to other local people in the area. I have been here for 12 years ... there is not much money in the area, you know', says another host.

This experience is readable through people and spaces that are now under intense displacement pressure. This is because gentrification is about both the transformation of the

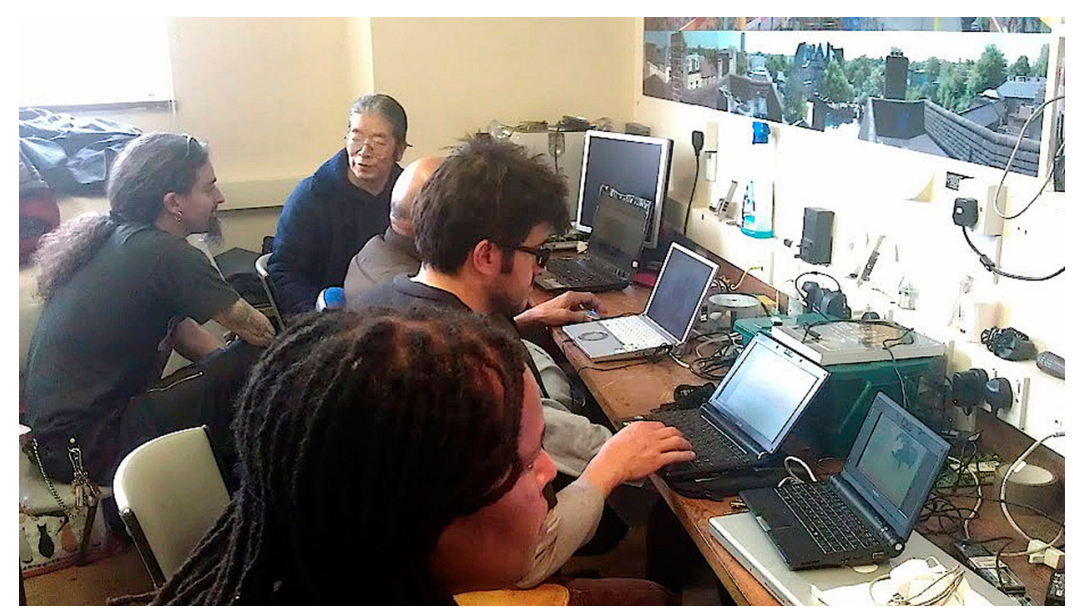

Figure 5 Wireless Wednesday at bitspace. Depfford-Greenwich border (Source: sps.org archive, Creative Commons license). 
commons into the neo-liberal privatisation of space and the displacement of working-class residents and their everyday cultural practices, attitudes and lifestyle (Figure 5).

\section{Concluding remarks: Icarus on the ground}

According to OWN developers, its likely scenario is to evolve towards ad hoc services, such as on-demand file-sharing between peers, or very localised forms of collection and dissemination of 'smart' data (probably sensors about local environmental issues or digital storytelling).

'OWN was about operating an independent infrastructure. [...] We are now evolving towards a model similar to the Intranet of the 90s: "walled gardens" of off-line networks.' (James, founder of OWN)

In a sense, within the wireless reach of a mesh network we have an inversion of the paradigm of Internet freedom. Wireless mesh can rather perform as a closed network, potentially offering the freedom of tailored services away from the surveillance gaze-of the state or commercial tracking. Another way of seeing this is in terms of the market's failure to provide certain services: secure digital connections and unrestricted access to, or sharing of, digital resources.

To my mind, the problem wireless networks like OWN face is the coming together of two opposite forces. One direction pulls towards the 'local', in sharing resources and data, bandwidth and bulletins, usually within the limited reach of the wireless wave. But the 'local' is not just the locus for direct involvement, and neither is it intended as an opposite to the 'global'. Importantly for the functioning of OWN, the local is where a gift economy of exchange and expectations materialises. ${ }^{14}$ This gift economy is expressed via the sociality of the mesh, for instance, in relation to outreach of new hosts and negotiation of bandwidth provision in commons.

The other force seems to tear apart the neighbourliness on which experiences like
OWN rely. This is a result of the ongoing privatisation of residential solutions for new upmarket buyers and the consequent displacement of working-class residents. The paradox of 'proximity' in a gentrifying neighbourhood-wireless networks are necessarily territorial-puts a slightly different notion of the 'just city' at the centre of the organisation and maintenance of an open wireless network. From my preliminary research, there is a sense in which new enclaves of luxury flats can limit the outreach efforts for new nodes. This is for two sets of reasons. Firstly, because the physical city now boasts more secluded enclaves. Secondly, and more importantly, the gift economy on which OWN is based might be negatively affected by individualised lifestyles and consumerist aesthetics.

This is to say that gentrification operates on two interconnected levels. The first and more obvious level is that it expresses a neo-liberal reorganisation of urban space, because it forges residential opportunities that are only suitable for and accessible to middle-class people (direct and exclusionary displacement). The second level is the flipside of the previous one, although it is often concealed (see Slater 2006): gentrification implies the cultural displacement of working-class residents, with their disposition and practices of sharing resources, caring for one another and their social networks.

More longitudinal research is needed to establish what evolutionary trajectory OWN will take in relation to the changing urban scenario that hosts it. This paper has suggested the centrality to OWN of a working-class cultural disposition for sharing and caring in commons, as users and hosts of the network have showed me in the last few years. Its unstable patchwork improvisation, made of places, people and technologies, may indeed result in a resilient response to neo-liberal organisation of urban space: an utterance in the planned and organised city. ${ }^{15}$ Whatever course OWN will take, it can be hoped it will continue to limit, at least on exclusionary and cultural 
grounds, the displacement that new-build gentrification has been perpetrating in Deptford and inner-city London in the past years.

\section{Disclosure statement}

No potential conflict of interest was reported by the author.

\section{Notes}

$1 \mathrm{http}: / /$ kiddingthecity. org

2 This is the 'box' that allows the wireless network to communicate between nodes. In a mesh network, all routers connect to each other using a software interface. When a router fails, this software automatically calculates a new route to the destination.

3 I take this chance to thank my anonymous peer reviewers too.

4 I describe the network in the next two sections. More technical details on mesh networking are available at: https://en.wikipedia.org/wiki/Mesh_ networking

5 The river Ravensbourne enters the Thames at Deptford and divides the borough of Greenwich and Lewisham. Its tidal reach is known as Deptford Creek.

6 At the time of writing this piece, OWN secured some extra funding and new partners, see: http:// spc.org/mazi-mondays/

7 https://coopepys.wordpress.com/about/ (please read the Response to 'About'). Also see: http://tiny. $\mathrm{cc} / \mathrm{xdas} 4 \mathrm{x}$

8 The estate was at the time half-empty and run down, and deemed 'unfit' for the accommodation of families (Steele 1993).

9 See the report commissioned by the developers of the controversial Convoys Wharf on Deptford Riverside: http://futurecity.co.uk/portfolio/ convoys-wharf/

10 Developer's brochure, my emphasis: http://www. creekside-kentwharf.co.uk/

11 Developer's brochure, my emphasis: http://www. creekside-kentwharf.co.uk/

12 That was 2005: the planning for the terminal has more recently been located at East Greenwich Thames riverside.

13 The video is available on the excellent blog by Transpontine: http://transpont.blogspot.co.uk/ 2012/05/pete-pope.html

14 This tension between proximities and divergences, an open but off-line network, is rendered in OWN users' involvement with their local social landscape (Cardullo 2017).
15 I am deeply indebted to Anne Rademacher (New York University) for her inputs, suggestions and comments on this important point.

\section{ORCID} Paolo Cardullo (1) http://orcid.org/0000-
0001-8299-4915

\section{References}

Akyildiz, I. F., and Xudong Wang. 2005. "A Survey on Wireless Mesh Networks." IEEE Communications Magazine 43 (9): S23-S30. doi:10.1109/MCOM. 2005.1509968.

Alleyne, Brian. 2011. "Challenging Code: A Sociological Reading of the KDE Free Software Project." Sociology 45 (3): 496-511. doi:10.1177/ 0038038511399620.

Antoniadis, Panayotis, and lleana Apostol. 2014. "The Right(s) to the Hybrid City and the Role of DIY Networking." The Journal of Community Informatics 10 (3), http://ci-journal.net/index.php/ciej/article/view/ 1092.

Back, Les. 2009. "Researching Community and Its Moral Projects." Twenty-First Century Society 4 (2): $201-$ 214. doi:10.1080/17450140903000316.

Back, Les. 2015. "Why Everyday Life Matters: Class, Community and Making Life Livable." Sociology 49 (5): 820-836. doi:10.1177/0038038515589292.

Back, Les, and Dawn Lyon. 2012. "Fishmongers in a Global Economy: Craft and Social Relations on a London Market." Sociological Research Online 17 (2): 23. http://www.socresonline.org.uk/17/2/23.html.

Bar, Francois, and Hernan Galperin. 2004. "Geeks, Bureaucrats and Cowboys: Deploying Internet Infrastructure, the Wireless Way." In The Network Society: A Cross-Cultural Perspective, edited by Manuel Castells, 269-287. Cheltenham: Edward Elgar.

BBC. 2007. The Tower: A Tale of Two Cities. Documentary. Bijker, Wiebe. 2010. "How is Technology Made?-That is the Question!." Cambridge Journal of Economics 34: 63-76. doi:10.1093/cje/bep068.

Bijker, Wiebe, Thomas Parke Hughes, and T. J. Pinch, eds. 1987. The Social Construction of Technological Systems: New Directions in the Sociology and History of Technology. Cambridge, MA, London: MIT Press.

Brenner, Neil. 2009. "What Is Critical Urban Theory?" City 13 (2): 198-207. doi:10.1080/ 13604810902996466.

Cardullo, Paolo. 2017. "Urban Change and the Mesh: An Ethnography of Deptford's Open Wireless Network." In Communicating the City, edited by Giorgia Aiello, Matteo Tarantino and Kate Oakley. Peter Lang. http://tiny.cc/gt3aay. 
Centre for Urban and Community Research. 1997. Deptford City Challenge Evaluation Report. London: Goldsmiths University of London.

Coleman, E. Gabriella. 2012. Coding Freedom: The Ethics and Aesthetics of Hacking. Princeton: Princeton University Press.

Davidson, Mark, and Loretta Lees. 2005. "New-Build 'Gentrification' and London's Riverside Renaissance." Environment and Planning A 37 (7): 1165-1190. doi:10.1068/a3739.

de Certeau, Michel. 1984. The Practice of Everyday Life. Berkeley: University of California Press.

Forlano, Laura. 2008. "Anytime? Anywhere?: Reframing Debates Around Community and Municipal Wireless Networking." The Journal of Community Informatics 4 (1), http://ci-journal.net/index.php/ciej/article/ view/438.

Forlano, Laura. 2009. "WiFi Geographies: When Code Meets Place." The Information Society 25 (5): 344352. doi:10.1080/01972240903213076.

Forlano, Laura. 2013. "Making Waves: Urban Technology and the Co-Production of Place." First Monday 18 (11), http://128.248.156.56/ojs/index.php/fm/ article/view/4968.

Forlano, Laura, Alison Powell, Gwen Shaffer, and Benjamin Lennett. 2011. "From the Digital Divide to Digital Excellence." In New America Foundation. http:// www.newamerica.net/.

Foth, Marcus. 2003. "Connectivity Does Not Ensure Community: On Social Capital, Networks and Communities of Place." In ITIRA Conference.

Foth, Marcus. 2006. "Facilitating Social Networking in Inner-City Neighborhoods." Computer 39 (9): 44-50.

Foth, Marcus, Jaz Hee-jeong Choi, and Christine Satchell. 2011. Urban Informatics. In Proceedings of the ACM 2011 Conference on Computer, edited by Pamela Hinds, John C. Tang, and Jian Wang. New York, NY: Association for Computing Machinery. http://portal. acm.org/toc.cfm? id=1958824.

Foth, Marcus, Helen Klaebe, Barbara Adkins, and Gregory Hearn. 2009. "Embedding an Ecology Notion in the Social Production of Urban Space." In Handbook of Research on Urban Informatics: The Practice and Promise of the Real-Time City, edited by Marcus Foth, 179-194. Hershey, PA: Information Science Reference.

Graham, Stephen. 2004. "Beyond the 'Dazzling Light': From Dreams of Transcendence to the 'Remediation' of Urban Life: A Research Manifesto." New Media \& Society 6 (1): 16-25. doi:10.1177/ 1461444804039905.

Graham, Stephen. 2005. "Software-Sorted Geographies." Progress in Human Geography 29 (5): 562580. doi:10.1191/0309132505ph568oa.

Graham, Stephen, ed. 2010. Disrupted Cities: When Infrastructure Fails. New York: Routledge.

Graham, Stephen, and Simon Marvin. 2001. Splintering Urbanism: Networked Infrastructures, Technological
Mobilities and the Urban Condition. London: Routledge.

Harper, Douglas. 2002. "Talking About Pictures: A Case for Photo Elicitation." Visual Studies 17 (1): 13-26.

Harris, Andrew. 2012. "Art and Gentrification: Pursuing the Urban Pastoral in Hoxton, London." Transactions of the Institute of British Geographers 37 (2): 226-241. doi:10.1111/j.1475-5661.2011. 00465.x.

Harvey, D. 1978. "The Urban Process Under Capitalism: A Framework for Analysis." International Journal of Urban and Regional Research 2 (1-4): 101-131.

Hu, Tung-Hui. 2015. A Prehistory of the Cloud. Cambridge, MA: The MIT Press.

Isin, Engin F., and Evelyn Ruppert. 2015. Being Digital Citizens. London: Rowman \& Littlefield.

Jungnickel, Katrina. 2014. DIY WiFi: Re-Imagining Connectivity. Houndmills, Basingstoke, Hampshire, UK; New York: Palgrave Macmillan.

Keith, Michael. 2005. After the Cosmopolitan?: Multicultural Cities and the Future of Racism. 1st ed. New York, NY: Routledge.

Kitchin, Rob, and Martin Dodge. 2011. Code/Space: Software and Everyday Life. Software Studies. Cambridge, MA: MIT Press.

Klein, Hans K., and Daniel Lee Kleinman. 2002. "The Social Construction of Technology: Structural Considerations." Science, Technology \& Human Values 27 (1): 28-52.

Knowles, Caroline. 2010. "Mobile Sociology." The British Journal of Sociology 61 (January): 373-379. doi:10.1111/j.1468-4446.2009.01295.x.

Larkin, Brian. 2013. "The Politics and Poetics of Infrastructure." Annual Review of Anthropology 42 (1): 327-343. doi:10.1146/annurev-anthro-092412155522.

Lawton, Philip, Enda Murphy, and Declan Redmond. 2014. "Neoliberalising the City 'Creative-Class' Style." In Neoliberal Urban Policy and the Transformation of the City, edited by Andrew MacLaran and Sinéad Kelly, 189-202. UK: Palgrave Macmillan. http://link.springer.com/chapter/10.1057/ 9781137377050_12.

Lees, Loretta. 2000. "A Reappraisal of Gentrification: Towards a 'Geography of Gentrification'." Progress in Human Geography 24 (3): 389-408. doi: 10. $1191 / 030913200701540483$.

Lewisham Council. 2012. Deptford Creekside Conservation Area Appraisal. London: Lewisham Council Planning Service. http://tiny.cc/dstycy.

Mackenzie, Adrian. 2005. "The Performativity of Code Software and Cultures of Circulation." Theory, Culture \& Society 22 (1): 71-92.

Mackenzie, Adrian. 2011. Wirelessness: Radical Empiricism in Network Cultures. Cambridge, MA; London, UK: MIT Press.

MacKenzie, Donald A., and Judy Wajcman, eds. 1985. The Social Shaping of Technology: How the 
Refrigerator Got Its Hum. Milton Keynes: Open University Press.

Marcuse, Peter. 1985. "Gentrification, Abandonment, and Displacement: Connections, Causes, and Policy Responses in New York City." Washington University Journal of Urban and Contemporary Law 28: 195250.

Marcuse, Peter. 2009. "From Critical Urban Theory to the Right to the City." City 13 (2): 185-197. doi:10. 1080/13604810902982177.

Medosch, Armin. 2015. "Cities of the Sun: Urban Revolutions and the Network Commons." The Next Layer. September. http://www.thenextlayer.org/node/ 1358.

Michael, Mike. 2006. Technoscience and Everyday Life: The Complex Simplicities of the Mundane. Maidenhead: Open University Press.

Pratt, Andy C. 2009. "Urban Regeneration: From the Arts 'Feel Good' Factor to the Cultural Economy: A Case Study of Hoxton, London." Urban Studies 46 (5-6): 1041-1061. doi:10.1177/0042098009103854.

Prell, Christine. 2009. "Rethinking the Social Construction of Technology Through 'Following the Actors': A Reappraisal of Technological Frames." Sociological Research Online 14 (2), doi:10.5153/sro. 1913.

Rodgers, Dennis, and Bruce O'Neill. 2012. "Infrastructural Violence: Introduction to the Special Issue." Ethnography 13 (4): 401-412. doi:10.1177/ 1466138111435738.

Skeggs, B., and V. Loveday. 2012. "Struggles for Value: Value Practices, Injustice, Judgment, Affect and the
Idea of Class." The British Journal of Sociology 63 (3): 472-490.

Slater, Tom. 2006. "The Eviction of Critical Perspectives From Gentrification Research." International Journal of Urban and Regional Research 30 (4): 737-757.

Slater, Tom. 2009. "Missing Marcuse: On Gentrification and Displacement." City 13 (2): 292-311. doi:10. 1080/13604810902982250.

Spectacle and JRF. 2008. "The Case of the Towers." https://vimeo.com/7345466.

Star, Susan Leigh. 1999. "The Ethnography of Infrastructure." American Behavioral Scientist 43 (3): 377-391.

Steele, Jess. 1993. Turning the Tide: The History of Everyday Depfford. London: Deptford Forum Publishing.

Tarantino, Matteo, and Simone Tosoni. 2013. "Introduction: Beyond the Centrality of Media and the Centrality of Space." First Monday 18 (11), http://ojsprod-lib.cc.uic.edu/ojs/index.php/fm/article/view/ 4953.

Paolo Cardullo was Associate Lecturer at Sociology, Goldsmiths University of London and is currently a postdoctoral researcher at the National Institute of Regional and Spatial Analysis (NIRSA) at the University of Maynooth, Ireland. Email: paolo. cardullo@nuim.ie 